\title{
University student organizations in Ukraine: on-campus youth policy and social participation*
}

Mateusz Kamionka a

\section{Abstract}

There is a widespread view that youth (students) are deeply involved into various social activities during their studies. However, are the majority of university students' real participants and consumers of the local social agenda? The present paper critically examines the social activity of students in Ukraine. It focuses on several inter-related issues, namely how often students are socially active, how they feelabout their immediate surrounding, and its influence. The author also researches the attitudes of university youth towards student organizations and activities they provide, paying special attention to analysis of universities' internal youth policy.

The paper also seeks to diagnose, describe and explain the behavioural patterns of social activity dominating the social consciousness of students in their local environment. Overall, the results of the study are not very optimistic. They clearly indicate that students experience tangible engagement and interaction problems inside the academic and social environment at their universities.

Keywords:Students. Youth. Youth NGO. Student Organizations. Student Activity. Social Activity at Universities.Students' Unions.

\section{Introduction}

We all accept the slogans: "Young people should show civic attitudes", "Students should be active", "Young people must participate in the life of the University". However, these postulates are not easy to implement in any country. Thirty years after Ukraine regained its independence and the creation of autonomic political student councils, the situation is still not perfect. Sociologists signal

\footnotetext{
* In this article, the author, used data obtained as part of a research project financed by the Polish National Science Center (grant number: 2016/23/D/HS5/00902). The author was the main contractor for the grant.

a University of Cracow, Cracow, Poland.
} 
the phenomenon of nowadays young people focusing on personal goals and self-centered values. The problem is still the formation of altruistic attitudes expressing oneself concern for the welfare of another human being and impersonal goals - and civic attitudes focused on the community, care for the environment, respect for the law, and for others and provide benefits for the common good. The new generation that was born in democracy, and is not so interested in policy and civic active represents what Marzęcki calls "Democratic natives" (2017). Because of that universities should play a significant role in the development of a culture of social participation not only through the process of educational activity, but also through active collaboration with regional companies, cultural sector and municipal government (KAŹMIERCZYK et al., 2019, p. 62). Stimulating activity is the responsibility of parents, educators (Universities), as well as state institutions and authorities, which should create conditions conducive to the participation of young people in the decision-making process at various levels of local community management, but also the University or the state. However it is commonly believed that during studies the most significant number of young people spend most of their time learning and working in non-governmental and student organisations (e.g. local student governments or in post-soviet countries - student unions, "студенческийррофком"). Is it true? The author of the article conducted quantitative and qualitative research involving 1,043 and 16 youth from various parts of Ukraine respectively, which will help answer these questions (we can assume that the research sample is a representative for Ukrainian youth).

\section{Education in a present-day Ukraine}

After the collapse of the Soviet Union in 1991, where Ukraine was one of the key member republics, the Ukrainian Higher Education system faced a number of considerable problems. Both serious and minor flaws were aggravated by instances of systematic corruption (ROZHANS'KA, 2016). Gaining of independence sparkled an explosive growth in the numbers of Higher Education institutions, particularly of universities and academies. In the 1st year of independence (academic year 1991/1992), there were 742 colleges and technical schools (vocational Education was a key element of the soviet educational system) and 149 universities and academies. This phenomenon was accompanied by numerous abuses and violations. Alongside this, more students meant more money and since the quantity of students tripled, many poorly qualified students obtained their degrees. After 30 years, the number of technical schools decreased to 338, and the number of universities and academies almost doubled to 281 (DERZHAVNA SLUZHBA STATYSTYKY UKRAYINY, 2020). Ukraine ended up with one of the highest High Education participation rates in the world with $70 \%$ of 18 year olds enrolling in High Education (1.7 million students in a country of 45 million 
people) (BRITISH COUNCIL, 2015). The situation changed dramatically after 2014, when following the so-called "Revolution of Dignity" (sometimes also called the "Euro-Revolution") country took a pro-Western course, one of the priority changes was the reform of High Education. Formally, Ukraine became a full member of the Bologna Process since 2005 (NIKOLAEVA, 2017), but only after almost 10 years the system came closer to the European standards of High Education. The current reform of High Education was enforced by introducing the Law of Ukraine "On Higher Education" (UKRAINE, 2014). According to this law, the scientific and qualification levels in the High Education system were transformed and fully harmonized with the Bologna agreement. Although High Education in Ukraine is free for all citizens and government supports some areas of study by providing free admissions and full-scale scholarships, there are certain limitations for students. For example, if a person fails application to some High Education institution due to a poor graduation test result, she/he needs to either pays for your tuition, change field of study or look for a free place at some other institution (most likely of a lower level or prestige). Anyway, in spite of all governmental activities, the process of transformation seems to be long and it is definitely the young generation of scientists, lecturers and students, who will finish it in the coming years or/and will introduce some further transformations.

\section{The concept of youth: short review of the literature}

To set the conceptual background and avoid uncertainty we need to examine the definition of the term youth, which is often interpreted in many different ways- there is no single consistent definition. Similar ambiguity can be traced in case of defining boundaries between childhood and maturity resulting in no single conceptual definition shared by the researchers. For example, United Nations Educational, Scientific and Cultural Organization (UNESCO) uses different definitions of youth depending on the relevant context but they are all based on the United Nations (UN) definition, which defines "young people" as persons aged 15-24, without prejudice to other interpretations introduced by the member states, in order to ensure statistical coherence between regions. Thus, the UN youth statistics is grounded on this vision, as can be seen in the records of the UN Publishing House Statistics on Demography, Education, Employment and Health (UNESCO, 1981). Therefore, the article will present selected definitions because the category of youth is treated as a dynamic social structure (MESSYASZ, 2013). The adolescents are considered in the article as adults. However, they are just entering adulthood (the so-called young adults), who, from the sociological point of view, can be characterised by professional and economic dependence, which results from continuing their Education in High Education. Although it is still subject to the process of Education, socialisation 
and gaining experience (RODZIEWICZ, 2015), their social action may be a determinant of their plans and life behaviours.

It is assumed that in Ukraine, young people are between 14 and 35 years of age (UKRAINE, 2021), The European Union, on the other hand, legally defines youth (e.g. in social programsYouth in Action and Erasmus + ), as people between the ages of 13 and 30 (EUROPEAN COMMISSION, 2021). Of course, these definitions are straightforward and do not fill the entire methodological gap; therefore, more complex definitions should be used. The Hungarian sociologist Karl Mannheim formulated the concept of the definition of youth, considered to be the basic generational one, in which he emphasised that: "generations are not only biological categories determined based on the criterion of age, but are the result of social and historical processes. Mannheim's concept was a breakthrough in the current thinking about a generation that was no longer treated literally as a biological and age-related phenomenon, but the result of complex social processes (KOZAKIEWICZ, 1988). According to this concept, those are the generations that determine the shape of the entire society. He emphasised that "youth is a factor that dynamises the social structure, bringing to it innovative, characteristic and necessary values for industrial societies". We should mention here that in the $21 \mathrm{st}$ century it is the pro-social work for a collective or student group, or example one village or district, which can be considered as an innovative value and needed to build a civil society (PRAUZNER, 2010). The changes of generations accelerate and become more dynamic as faster, as faster the society changes, and thus the socio-cultural and technological environment. Mannheim also called "youth" one of the secret resources that exist in every society and whose mobilisation depends on the vitality of that society. He attached great importance to it, defining its social function, arguing that the importance of youth in society is not stable and the issue of its use depends on the nature and social structure of society as well as its culture (MANNHEIM, 2010, p. 571).

In the article author will definitely present data connected to the young generation of Ukraine, because the study that was made, included youth studying in Ukrainian universities (dominanta and median were 19 years old $-99 \%$ of respondents were aged $18-25$ y.o.).

\section{Youth as an element in the social transformation processes}

The social category refers to the perception of youth as a certain social group obliged to acquire the skills of full and responsible participation in the life 
of a community. Eisenstadt (1996), who is representative of the functional approach, notices in young people certain predispositions that allow them to fulfil many functions. For him, young people are individuals who, due to their age, remain in a state of transition between the process of primary and secondary socialisation. Since they are not sufficiently prepared to function independently, they create peer groups that meet their needs for belonging and security and equip them with knowledge characteristic of adults, thus ensuring the maintenance of balance in society. Filipiak (2003) provides a separate definition. According to him, young people can be treated not only as a social group (more often) but also as a social category (less often) bringing together young people in a chronological and biological sense. In this sense, this category associates with youth. The term youth "refers to a set of individuals in a specific age group, and the term youth refers to the state they experience. The cultural approach, on the other hand, considers young people as a group with a culture and characteristics different from that in which adults are functioning". This direction includes the theory of the transmission of cultural values created by Mead (1978), according to which young people adapt their behaviour to the specificity of the prevailing culture, learning it and passing it on to the next generations. Treating culture as the dominant factor in the perception of youth is also postulated by Chałasiński (1958, p. 39), who writes that "youth is not a natural physiological and hormonal state, but an element of culture, a "social institution" whose shape depends on the structure and culture of society". Youth is characterised by freedom, release from certain social responsibility, economic dependence and premarital status. It is not age or other biological criteria, but social customs that determine the duration of this period, the nature and limits of freedom. Societies clearly and lucidly define the personality and social models, duties and privileges of young people, because it enables them to develop and maintain the culture they have created. Ilyinsky (1999, p. 24) emphasises, however, that the definition of the term "youth" is closely related to historic conditions. Nobody can form a single definition valid for a long period of history, and it depends on the nature and level of development of a society. It is impossible to create a single definition once and for all, an acceptable universal concept of "youth" that has never existed in the world and never can be. When we talk about youth as a factor of change, we should refer to Mannheim's (2010) classic definition, according to which young people belong to those hidden resources that are available to every society and whose mobilisation depends on its vitality. It is also the kind of reserve that comes to the fore when society faces the challenge of adapting to rapidly changing or completely new circumstances. This context is the result of two other premises concerning change and youth. Youth is a natural reservoir of innovation resulting from the specificity of development of 
this phase of life. It includes special receptivity, sensitivity, the need to define "oneself" by referring to important ideas and events. A sense of one's own "peripherality" and marginality combined with criticism and reflectiveness is also important. Youth is also a natural ally of change, which - increasing tensions - always expresses the need for behaviour that creates a new reality. Therefore, each change creates opportunities for innovation of young people. Even the combination of these two perspectives requires close attention to the relationships that arise between the youth and social systems. According to the Spanish philosopher Ortega y Gasset (1992), the most important concept in history is the concept of a generation. Changing generations is like a neverending story of continuation and change, on the transfer of ingrained norms, values and patterns of behaviour, on the one hand, and on the other hand - on generating one's ideas and attitudes in response to socio-economic and cultural changes. Parsons (1962, p. 97-123), using the American example, defined the functionalist image of youth in modern society, where he explained their problems as "frictions" in the development process of "society in transition". It is the development of the modern world with an emphasis on science and technology, the global process of economic development or new social movements (feminism, minorities, e.g. sexual) that put pressure on modern society, somehow defining its direction of development. Parsons also associates scientific progress with the reach of the educational system, especially at the higher level. The prolongation of formal Education, the pressure of graduating from High Education, not from high school as it was earlier, creates new requirements for young people, and thus for the family they come from, and the one they are supposed to create. The "loss of functionality" of the family and the simultaneous "gaining of autonomy" resulting from the new organisation of the production process of modern society is a potential cause of tensions between increasing expectations and increasing independence - an area of choice resulting from changes in the differentiation of the social structure. The problem with assimilating new values is primarily young people who feel these changes more than other groups. Changing the meaning of moral and social principles and values leads to orientation problems of young people and is associated with difficulties in the personal adaptation of an individual to social organisations. Ukrainian political scientist Karnaukh (2005) sees young people as the embodiment of the future of society. Youth is not a passive observer of the processes and changes taking place in society; they even want to join these processes. According to Karnaukh (2005), young people are the main driving force behind the progressive socio-political development of the politically conscious people of Ukraine. The same tendency is shown by Kamionka (2019, p. 80-92), who emphasizes the enormous role played by students in the Ukrainian "colour revolutions". Are young Ukrainians really a 
manifestation of the "wind of change" in Ukrainian society? Let's talk more about that further below.

\section{Research methodology}

Two methods were used to examine the level of social involvement of student youth in Ukraine. Author apply the first method to research young people was the individual depth interview (IDI) method, which is an example of a classic qualitative method. The interviews were conducted among 16 students from various regions of Ukraine; these were academic centres from Lviv (western Ukraine), Uzhhorod (south-western Ukraine), Nizhyn (northern Ukraine), Sumy (eastern Ukraine), Pereiaslav (central Ukraine) and the capital - Kyiv. Students for in-depth interviews were randomly selected from among the most socially active students in a given academic centre. The interviews were accompanied by the quantitative research- an auditorium survey among students (full-time) at selected universities in Ukraine. In the case of the questionnaire survey, the research sample consisted of 1,043 respondents from Ukraine. Purposeful random sampling was used. The universities were selected purposefully to ensure a relatively high level of geographical differentiation of the sample. In the random phase, it was multi-stage sampling. For this purpose, previously defined sets were used, and their nature results from the essence of the phenomenon under study. Fourteen universities were selected purposefully to ensure a relatively high level of territorial differentiation of the sample. At the same time, in the random phase, the first-degree sampling units were faculties, the second - institutes/departments, the third - fields of study, and the fourth - grades of students. The qualitative research questionnaire consisted of 86 questions and a record; the research was conducted from the second half of 2017 to the end of 2018 in Kharkiv, Nizhyn, Kherson, Chernivtsi, Kyiv, Dniepr, Hlukhiv, Poltava, Sumy, Lviv, Odesa, Pereyaslav, Uzhgorod and Vinnytsia. The research was conducted in compliance with relevant ethical principles. All the data was collected anonymously and the results were used for research purposes only.

The main goal of the author of this article is an attempt to describe and explain to what extent Ukrainian student youth is socially active. In the course of the statistical analysis, the following research hypothesis will be tested:

H1: Ukrainian youth are socially active in many ways (both inside and outside the university).

1 The term refers to the famous song by Scorpions- Wind of Change. 
In the further part of the work, an additional hypothesis will be justified using the results of qualitative research:

H2: Students see a serious problem in the activity of student NGOs and do not participate in student organisations work.

\section{Results}

At the very beginning, it was worth finding out whether the academic youth was socially active at the local level (city district, village, town, religious community, immediate neighbourhood) in the previous year. Table 1 shows that only $42 \%$ of the surveyed youth was socially active in any way; while more than $56.1 \%$ were not involved into any local social work. It is a worrying result that highlights certain shortcomings related to the civic Education of a young Ukrainian citizen. The period of studies, however, should increase the opportunities for youth to be active. In most academic centres there is huge offer for students in non-governmental or student organisations.

Table 1 - During the LAST YEAR, did you ever engage in activities for the benefit of the local community (region, town, parish, immediate neighbourhood)?

\begin{tabular}{lccc}
\hline & & Frequency & Percent \% \\
\hline \multirow{3}{*}{ Valid } & Yes & 438 & 42,0 \\
& No & 585 & 56,1 \\
& Altogether & 1,023 & 98,1 \\
\hline Missing data & System data gaps & 20 & 1,9 \\
\hline Altogether & & 1,043 & 100,0 \\
\hline
\end{tabular}

Source: Author's study (2020)

Another question was to show whether there is a difference in social activity among students according to the language they use at home. As we can see on Graph 1 , among each language group, the majority of people who have not shown any social activity in the last year. However, the highest number of active students is among those declaring the use of Ukrainian (47.7\%), slightly fewer students using Surzhyk $^{2}$ (43.4\%), and the least are Russian-speaking students (37.6\%). More than $10 \%$ of the difference between Ukrainian and Russian-speaking students is puzzling. It may be a result of the development of civil society in individual

Surzhyk- refers to a range of mixed (macaronic) sociolects of Ukrainian and Russian languages used in some areas of Ukraine and adjacent lands. 
regions of Ukraine, but also show a smaller offer of NGO's for the student in areas where mostly Russian-speaking students live.

Graph 1 - The activity of the surveyed youth for the benefit of society, according to the language they use

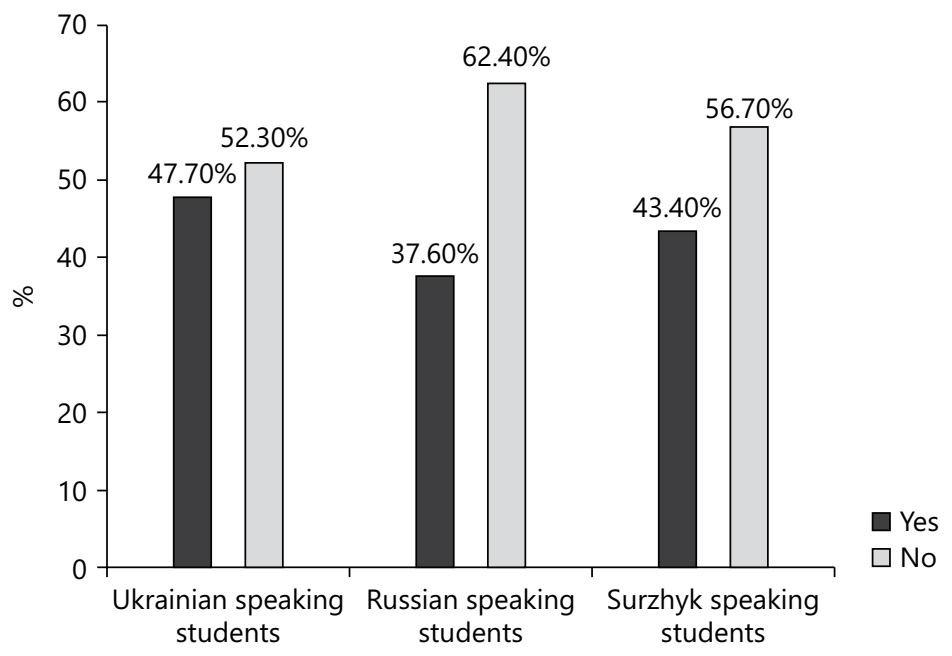

Source: Author's study (2020)

Table 2, on the other hand, shows the relationship with the groups that the student has. The results can answer the question of the motivation of young people's social involvement. The students bestow the most substantial emotional relationship with family $(75.8 \%)$, along with a strong relationship, as many as $94.3 \%$ of the respondents. Only $64.2 \%$ of young people feel a relationship to their village or city, which is a result that may indicate that in more than half of the students there is a need for a relationship and help for the local community. $62.9 \%$ of young people feel a slightly lower bond with their university. However, only $14.3 \%$ of all respondents feel a bond with a student organisation operating at the university or a local non-governmental organisation. The answers clearly show that despite the emotional ties they feel towards the local community or the university, non-governmental organisations are to blame for youth inactivity. Moreover, 19.4\% answered "hard to say", which may indicate that students do not even know the offer of student organisations or non-governmental organisations from their surroundings. 
Table 2 - How strong feeling do you relate to these groups or environments?

\begin{tabular}{|c|c|c|}
\hline & & Percent \% \\
\hline \multirow{5}{*}{ Family } & I feel a very strong connection, and I identify with this group & $75,8 \%$ \\
\hline & I feel a strong connection with this group & $18,5 \%$ \\
\hline & I feel a weak connection with this group & $3,6 \%$ \\
\hline & $\begin{array}{l}\text { I do not feel connected to this group at all, and I do not } \\
\text { identify with it at all }\end{array}$ & $1,1 \%$ \\
\hline & Hard to say & $1,0 \%$ \\
\hline \multirow{5}{*}{$\begin{array}{l}\text { My village } \\
\text { or city }\end{array}$} & I feel a very strong connection, and I identify with this group & $18,3 \%$ \\
\hline & I feel a strong connection with this group & $45,9 \%$ \\
\hline & I feel a weak connection with this group & $25,7 \%$ \\
\hline & $\begin{array}{l}\text { I do not feel connected to this group at all, and I do not } \\
\text { identify with it at all }\end{array}$ & $7,4 \%$ \\
\hline & Hard to say & $2,8 \%$ \\
\hline \multirow{5}{*}{ University } & I feel a very strong connection, and I identify with this group & $14,9 \%$ \\
\hline & I feel a strong connection with this group & $48,0 \%$ \\
\hline & I feel a weak connection with this group & $29,2 \%$ \\
\hline & $\begin{array}{c}\text { I do not feel connected to this group at all, and I do not } \\
\text { identify with it at all }\end{array}$ & $4,0 \%$ \\
\hline & Hard to say & $3,9 \%$ \\
\hline \multirow{5}{*}{$\begin{array}{l}\text { Some } \\
\text { organisation } \\
\text { or association } \\
\text { (local or } \\
\text { university } \\
\text { NGO) }\end{array}$} & I feel a very strong connection, and I identify with this group & $3,6 \%$ \\
\hline & I feel a strong connection with this group & $10,7 \%$ \\
\hline & I feel a weak connection with this group & $27,5 \%$ \\
\hline & $\begin{array}{l}\text { I do not feel connected to this group at all, and I do not } \\
\text { identify with it at all }\end{array}$ & $38,8 \%$ \\
\hline & Hard to say & $19,4 \%$ \\
\hline
\end{tabular}

Source: Author's study (2020)

The second part of the research consists of interviews with active students (the condition was participation in the student council or student organization) from different parts of Ukraine: west, center, south, east (the article presents only a part of over one hour interviews). In qualitative research, students where ask the following questions:

- How would you describe the student organisations? What role do they play in university life? Do they influence the reality outside the university?

- Do students need such organisations? Why? 
Students from different parts of Ukraine agreed on the sense of the existence of student organisations. Each answer showed that the interviewed students positively responded to the very idea of student organisations operating at universities.

Students need such organisations; they implement the ideas of students (Lviv).

They are needed because they are informal organisations that allow discovering (develop) beyond science (Nizhyn 3).

Students from Kyiv and Pereyaslav emphasised that there are many student organisations, but not all of them work realistically. Furthermore, often he only deals with things aimed at keeping students entertained. It can be observed that this division may naturally cause conflicts between groups of students. Today young people pay more attention to Education, which importance was undermined in the 1980-90s (GORSHKOV, KLYUCHAREV, 2011, p. 22).

I would divide them into two categories: formal and real organisations. The formal ones are only registered, but they do not carry out any activity (Kyiv 1).

Student organisations are active (effective) and passive (ineffective). Active have informed members and ordinary leaders who run the organisation properly. These organisations care for the welfare of the university itself (Kyiv 2).

For example, our organisation tries to get involved and solve problems of students, help in stressful situations and they come to us. By law, there is one more organisation, the Student Council, the primary purpose of which is to fight for the rights of students, but in fact, the Student Council organises parties. We have to cooperate with the rector and vice-chancellors, but unfortunately, it is complicated, because apart from the fact that they do not want to help and cooperate with us, they do nothing at all and only disturb (Pereyaslav 2).

Students also noticed the problem of student unions, which for them are a relic of the previous communism system, and today they focus only on taking part in the scholarship from students (unions take some small percent of money from all students scholarship-for collective purposes). They are also outraged by the fact 
that the people working (they are often so-called eternal students) there full-time and are often guided only by material benefits.

There are different types of student organisations: there are those who think about their comfort and influence, there are those who gather people and work for active students, make some changes and innovations, but there are also those who only work to get projects and this money, but there is little of them (Sumy 2).

Organisations are made to improve students' lives, at least that is how it always has been, but now everything has changed. For example, unions ("profspilka") for students used to work well for students, but now people understand how you can earn money by writing projects for such organisations as well as student councils (Sumy 1).

We have a few organisations at the university: the student council and the trade unions (profspilka), which has been operating since 2008, but they are still remnants of the communism; they do nothing at all except that they collect money from the scholarship. I often mentioned the reorganisation of "unions", because why should they how full-time jobs there, if we have a student council and a local government and I think that they could efficiently deal with everything themselves (Uzhgorod 1).

There is a number of young people who see the need for systemic changes in the structure of university organisations:

University, local society and students, generally need students organisations, but not what they are now. Organisations at the university need to be modernised (Sumy 1).

I think organisations work inside universities, but not outside of them. They do not play any role (Lviv).

Students need student organisations. In my opinion, we have to imitate the organisations in the US, where there are many different types of organisations at one university, and each one works in its direction. It would be nice if at our university it would be like this: various organisations that work in the interests of students. Let it not be one or two organisations, but more (Pereyaslav 2). 
Moreover, for those who see the enormous advantages of working in student NGOs:

In my opinion, student organisations, research clubs, student councils have a significant impact on the university and beyond. For example, members of the student council often take part in city events; they are often the organisers of such events. By doing such things, they firstly create a positive opinion about the university and secondly they help the city (Pereyaslav 3 ).

University non-governmental organisations, in my opinion, do not have much influence on what is happening outside the university. The university administration may hear their opinion and do something about it, but outside the university, I doubt it... I think so because students can organise themselves quickly, if they see their goal, then their activity can be noticed... and they are noticeable by the university administration, lecturers, then I can make a difference (Nizhyn 1).

A summary of this part will be an approximation of the results of young people's responses to the question about their views on whether there is a higher chance of achieving success now than 20 years ago (Table 3). The answer, however, gives hope and optimism, $55.1 \%$ of the surveyed students believe that their older colleagues 20 years ago had lower chances of achieving success than those studying today.

Table 3 - Do you think nowadays youth in Ukraine have a greater or lesser chance of achieving success in life than their peers had 20 years ago?

\begin{tabular}{lccc}
\hline & & Frequency & Percent \% \\
\hline & Bigger & 208 & 19,9 \\
& Rather bigger & 367 & 35,2 \\
Valid & Same & 142 & 13,6 \\
& Rather smaller & 103 & 9,9 \\
& Smaller & 33 & 3,2 \\
& Hard to say & 160 & 15,3 \\
\hline Missing data & Altogether & 1,013 & 97,1 \\
\hline Altogether & System data gaps & 30 & 2,9 \\
\hline
\end{tabular}

Source: Author's study (2020) 


\section{Discussion and summary}

Students are undeniably the future of the nation, since the previous generations create conditions for the socialisation of new generations, and thus it is the youth that open up new vistas. However, the research does not show any definite conclusions. Young people in Ukraine are not often socially active, the same trend is shown by Golovchin and Leonidova (2014) on the example of part of Russian Federation (this problem is not only unique to Ukraine or Russia, see more: BEKKERS, 2005; KENNEDY, 2007; MARZECCKI 2020; NG, 2009). Nonetheless, when we consider political problems in Ukraine it is interesting to note that there is a significant difference in the activity of Russian and Ukrainianspeaking students, which can only cause stratification in terms of social activity in specific regions of the country. Thus, the main hypothesis contained in the article was refuted. Most young people are not active, even though more than half of them feel a strong bond with the local region (city, village) where there live or where they study, or as well with the university. It may be the result of the old systems of social activity in Ukrainian universities, which do not meet their goals today and are a relic of communism (student even make examples about students union and "taking their money from scholarships"). In sum, universities in Ukraine must reform student councils and student organizations to take advantage of the sense of connection that young students have with their universities. After the graduation young people will probably not be socially active, if they are not involved into such activities during their studying. Social involvement of students is very important, especially in countries that build up their identity after the lack of state empowerment (ATSUNGUR, 2013, MARZECKI, 2020; NIKOLAYENKO, 2007).

Moreover, students' organisations should not focus only on providing social and cultural assistance; the surveyed students replied that the offer should be extensive and be more suited to the individual needs of smaller groups than to collective ones. Therefore, the second hypothesis was confirmed, showing the numerous problems faced by the community of student self-government and young NGOs. It is also important to emphasise that students believe that they have a better chance of their development today than their older colleagues had 20 years ago. Since 2014 there are ongoing military activity in Eastern Ukraine and young people are most often directly or indirectly involved into it. However, as the previous research shows, hybrid war does not affect the level of patriotism among youth (KAMIONKA, 2020a). It is hard not to notice that their social activity is more focused on surviving the current social and economic situation. At the same time, this does not stop youth from being socially active, it is the information for contemporary and future student leaders or universities 
that students today want to act; they only need mobilisation. We should not forget that the rapid economic changes related to the "western" transformations of Ukraine, will bring significant changes in the labour market.As a result, students will choose work more often than social activity during their studies. Therefore, the academic community (youth NGO, students' self-governments etc.) should already adapt to these changes, offering students more entertaining activities (including those needed in the labour market). Without it, the idea of a youth movement may disappear or become elite, as is often the case in the European Union countries. As a post-Soviet country, Ukraine still has a large number of social problems, e.g. corruption or the pressing necessity to conduct expeditious reforms.Young people are generally aware of such social problems, and although they sometimes doubt about democracy in Ukraine (KAMIONKA, 2020b), they think that they live better than before, and that their generation will change the country. High Education system can and should assist in this and provide all the possible support for social transformation and change. 


\section{Organizações de estudantes universitários na Ucrânia: política juvenil no campus e participação social}

\section{Resumo}

Há uma visão generalizada de que os alunos estão profundamente envolvidos em várias atividades sociais durante seus estudos. Mas será que a maioria dos universitários são verdadeiros participantes e consumidores da agenda social local? O presente artigo examina criticamente a atividade social dos estudantes na Ucrânia. Centra-se em várias questões inter-relacionadas, nomeadamente com que frequência os alunos são socialmente ativos, como se sentem sobre o ambiente que os cerca e a sua influência. $O$ autor também pesquisa as atitudes dos jovens universitários em relação às organizações estudantis e às atividades que elas oferecem, prestando especial atenção à análise da política interna da juventude nas universidades. $O$ artigo também busca diagnosticar, descrever e explicar os padrões de comportamento da atividade social que dominam a consciência social dos alunos em seu ambiente local. No geral, os resultados do estudo não são muito otimistas. Eles indicam claramente que os alunos experimentam problemas tangíveis de engajamento e interação dentro do ambiente acadêmico e social em suas universidades.

Palavras-chave: Estudantes. Juventude.ONG Juvenile. Organizações Estudantis. Atividade Estudantil. Atividade Social nas Universidades. Sindicatos Estudantis.

\section{Organizaciones de estudiantesuniversitariosenUcrania: política juvenil enel campus y participación social}

\section{Resumen}

Existe una opinión generalizada de que losestudiantesestán profundamente involucrados en diversas actividadessociales durante sus estudios. ¿Sin embargo, lamayoría de losuniversitariossonverdaderos participantes y consumidores de la agenda social local? El presente artículo examina críticamentelaactividad social de losestudiantesenUcrania. Se centra envarios temas interrelacionados, a saber, lafrecuenciaconla que losestudiantesson socialmente activos, cómo se sienten acerca de su entorno inmediato y suinfluencia. El autor tambiéninvestigalasactitudes de losjóvenesuniversitarioshacialasorganizacion esestudiantiles y lasactividades que realizan, prestando especial atención al análisis de la política interna de juventud de las universidades. El artículo también busca diagnosticar, describir y explicar lospatrones de comportamiento de laactividad social que dominanlaconciencia social de losestudiantesensu entorno local. Los resultados delestudio no sonmuy optimistas; indican claramente que losestudiantesexperimentan problemas tangibles de participación e interacción dentro del entorno académico y social en sus universidades.

Palabras clave:Estudiantes.Juventud.ONG Juvenil.OrganizacionesEstudiantiles. ActividadEstudiantil.Actividad Social en Universidades.SindicatosEstudiantiles. 


\section{References}

ATSUNGUR, G. The role of political youth movements in the democratisation process of the contemporary Russia. International Journal of Social Inquiry, Bursa, v. 6, n. 2, p. 57-71, June 2013.

BEKKERS, R. Participation in voluntary associations: relations with resources, personality, and political values. Political Psychology, Oxford, L v. 26, n.3, p. 439-454, 2005.

BRITISH COUNCIL. Higher education in Ukraine: briefing paper. 2015. Available from: https://www.britishcouncil.org/sites/default/files/ukraine_he briefing_paper.pdf. Access in: 2021 Jul. 12.

CHAŁASIŃSKI, J. Society and education. Warsaw: PWN, 1958.

DERZHAVNA SLUZHBA STATYSTYKY UKRAYINY. Zaklady vyshchoyi osvity. 2020. Available from: https://www.ukrstat.gov.ua. Access in: 12 Jul. 2021.

EISENSTADT, N. S. From generation to generation: age groups and social structure. In: GRIESE. H. M. Sociological theories of youth. Cracow: Impuls, 1996.

EUROPEAN COMMISSION. Commission Staff Working Document. On EU indicators in the field of youth. Brussels, 2011. Available from: http:// ec.europa.eu/assets/eac/youth/library/publications/indicator-dashboard_en.pdf. Access in: 2021 Jul. 12.

FILIPIAK, M. From subculture to alternative culture: introduction to youth subcultures. Lublin, UMCS, 2003.

GOLOVCHIN, M.; LEONIDOVA, G. Socio-cultural characteristics of the modern youth: some results of the pilot study. Economic and Social Changes: Facts, Trends, Forecast,Vologda, v. 5, n. 35, p. 113-126, 2014. https://doi.org/10.15838/esc/2014.5.35.8

GORSHKOV, M.K.; KLYUCHAREV, G.A. Continuous education in the context of modernization. Moscow: IS RAN, 2011.

ILYINSKY, I. The youth of the planet: a global situation in the 90s, trends and prospects, Moscow: Voice, 1999.

KAMIONKA, M. Patriotism of the young generation in Ukraine in the era of hybrid war.Lithuanian Annual Strategic Review, Vilnius, v. 18, n. 1, p. 221-239, 2020a. https://doi.org/10.47459/lasr.2020.18.10 
KAMIONKA, M. Revolutionary patterns of behavior of Ukrainian youth student on the example of the Sumy „Revolution on the grass” in 2004.In: KUZMENKO, Y.; KAMIONKA, M. (eds.). Problems of European integration and democracy in awareness of Ukrainian and Polish youth. Nizhyn: Nizhyn Gogol State University Press; 2019. p.80-92.

KAMIONKA, M. The attitude of Ukrainian student youth towards democracy in Ukraine. Sociological Studios, Lutsk, n. 1(16), p. 6-13, 2020 b. https://doi.org/10.29038/2306-3971-2020-01-06-13.

KARNAUKH, A. Problems of youth policy in current Ukraine. Political Management, Kiev, n. 4, p. 63-69, 2005.

KAŹMIERCZYK, E.; et al. Social participation of Russian and Polish students in urban development. University Management: Practice and Analysis, Yekaterinburg, v. 23, n. 5, p. 53-63, Jan. 2019. https://doi.org/10.15826/umpa.2019.05.041

KENNEDY, K. J. Student constructions of 'active citizenship': what does participation mean to students? British Journal of Educational Studies,Birmingham,v. 55, n. 3, p. 304-324, Sep. 2007. https://doi.org/10.1111/j.1467-8527.2007.00381.x

KOZAKIEWICZ, M. Youth: theories of youth. In: SZEWCZUK, W. (eds.). Encyclopaedia of psychology. Warsaw: Innovation Foundation,1988.

MANNHEIM, K. Diagnosis of our time. Moscow: Govoryashchaya kniga, 2010.

MARZĘCKI, R. How to engage "democratic Natives"? Political sophistication as important determinant of civic activity of young citizens in new democracies (The case of Poland). Romanian Journal of Political Science, Bucharest, v. 17, n. 1, p. 135-169, summer 2017.

MARZECKI, R. The first generations of freedom: conditions and patterns of participation in the public sphere of Polish and Ukrainian students. Warsaw: Scholar Publishing House, 2020.

MEAD, M. Culture and identity: a study of the intergenerational distance. Warsaw: PWN, 1978.

MESSYASZ, K. Obrazy młodzieży polskiej w dyskursie prasowym. Młodzież o sobie i rzeczywistości spolecznej[The image of Polish youth in the press discourse. Youth about themselves and social reality]. Łódź, Publishing House of the University of Łódź,2013. 
NG, S.W. Transformation of students into active and participatory citizens: an exploratory study. Educational Research for Policy and Practice, Singapore, v. 8, n. 3, p. 181-196, Oct. 2009. https://doi.org/10.1007/s10671-009-9072-7

NIKOLAEVA, S. Bologna process in Ukraine: the decade anniversary. Naukovo-metodychnyyzhurnal "Inozemnimovy", Kyiv, n. 2. p. 16-22, Apr. 2017. https://doi.org/10.32589/im.v0i2.124062

NIKOLAYENKO, O. The revolt of the post-soviet generation: youth movements in Serbia, Georgia, and Ukraine.Comparative Politic, New York, v. 39, n. 2, p. 169-188, Jan. 2007. https://doi.org/10.2307/20434032

ORTEGA Y GASSET, J. Why do we return to philosophy? Warsaw: Spacja, 1992.

PARSONS, T. Youth in the context of American society. Daedalus, Cambridge, v. 91, n. 1, p. 97-123, 1962.

PRAUZNER, T. Wpływ nowoczesnych mass mediów na osobowość człowieka [The influence of modern mass media on the human personality]. Edukacja-Technika-Informatyka, Rzeszów, v. 2, p. 46-51, 2010.

RODZIEWICZ, M. Młodzież jako katalizator zmian społecznoekonomicznych w ujęciu strategii Europa 2020 [Youth as a catalyst of socioeconomic changes in terms of the Europe 2020 strategy]. Science notebooks Zbliżenia Cywilizacyjne, Włocławek, n. 11, p. 57-78, 2015.

ROZHANS'KA, N. Otto Vil'hel'm VOL'F Koruptsiya u vyshchiy osviti: porivnyal'nyy analiz sotsial'nykh uyavlen' studentiv ta vykladachiv VNZ pivdnya Ukrayiny. Naukovyy visnyk Mykolayivs'koho natsional'noho universytetu imeni V. O. Sukhomlyns'koho. Psykholohichni nauky, Mykolaiv, n. 1, p. 171-176, 2016.

UKRAINE. Law about Education. 2014. Available from: https://zakon.rada. gov.ua/laws/show/1556-vii. Access in: 2021 Jul. 12.

Ukraine. Law on the basic principles of youth policy. 2021. Available from: https://zakon.rada.gov.ua/laws/show/1414-20. Access in: 2021 Jul. 12.

UNESCO. Youth definition. General Assembly resolution 36/28. 1981. Available from: https://undocs.org/en/A/36/215. Access in: $2021 \mathrm{Jul} .12$. 


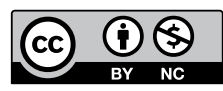

\section{Information about the author}

Mateusz Kamionka: PhD in Political and Public Administration Sciences, Assistant Professor, Institute of Political and Administration Science, Pedagogical University of Cracow, Cracow, Poland.Contact: mattkamionka@gmail.com

(iD) https://orcid.org/0000-0002-7316-145X 